\title{
UJI AKTIVITAS ANTIOKSIDAN EKSTRAK ETANOL KULIT BATANG MAHONI (Swietenia mahagoni Jacq.) MENGGUNAKAN METODE DPPH (1,1 diphenyl-2-picrylhydrazyl)
}

\author{
Turangan T. M. Amanda ${ }^{1)}$, Defny S. Wewengkang ${ }^{1)}$, Adithya Yudistira ${ }^{1)}$ \\ ${ }^{1)}$ Program Studi Farmasi FMIPA UNSRAT Manado, 95115
}

\begin{abstract}
Antioxidant are compounds that are able to inactivate the development of the oxidation reactions of the molecules or neutralize free radicals. Mahogany bark (Swietenia mahagoni Jacq.) has properties as a medicinal plant. Through the phytochemical screening, the mahogany bark (Swietenia mahagoni Jacq.) contains antioxidant compounds such as alkaloids, saponins and phenolics. The aim of this study was to determine the presence of antioxsidant activity in the extract of mahogany bark (Swietenia mahagoni Jacq.). using the DPPH method with a concentration of $250 \mathrm{mg} / \mathrm{L}, 200 \mathrm{mg} / \mathrm{L}, 150 \mathrm{mg} / \mathrm{L}$ and $100 \mathrm{mg} / \mathrm{L}$ and Vitamin C p.a as a positive control. Each sample made three repetitions of the test. The test uses a UV-Vis Spectrophotometer. The result of the study showed that mahogany bark (Swietenia mahagoni Jacq.) showed antioxidant activity with the percentage of $21,50 \%$ at the concentration at $250 \mathrm{mg} / \mathrm{L}$
\end{abstract}

Keywords : Swietenia mahagoni Jacq., Antioxidant, Ethanol, DPPH

\begin{abstract}
ABSTRAK
Antioksidan ialah senyawa yang mampu menginaktivasi berkembangnya reaksi oksidasi molekul lain atau menetralisir radikal bebas. Kulit Batang Mahoni (Swietenia mahagoni Jacq.) memiliki khasiat sebagai tanaman obat. Melalui skrining fitokimia, Swietenia mahagoni Jacq. Mengandung senyawa antioksidan seperti alkaloid, saponin dan fenolik. Penelitian ini bertujuan untuk mengetahui adanya aktivitas antioksidan didalam ekstrak tanaman Kulit Batang Switenia mahagoni Jacq. menggunakan metode DPPH dengan konsentrasi 250 mg/L, 200 $\mathrm{mg} / \mathrm{L}, 150 \mathrm{mg} / \mathrm{L}$ dan $100 \mathrm{mg} / \mathrm{L}$ dan Vitamin C p.a sebagai kontrol positif. Masing-masing sampel dibuat tiga kali pengulangan uji. Pengujian menggunakan alat Spektrofotometer UV-Vis. Hasil penelitian menunjukkan bahwa ekstrak Kulit Batang Swietenia mahagoni Jacq. memiliki aktivitas antioksidan dengan presentase sebesar $21,50 \%$ pada konsentrasi $250 \mathrm{mg} / \mathrm{L}$
\end{abstract}

Kata Kunci : Swietenia mahagoni Jacq., Antioksidan, Etanol, DPPH 


\section{PENDAHULUAN}

Senyawa antioksidan merupakan senyawa yang dapat menetralkan atau meredam radikal bebas, serta menghambat terjadinya oksidasi pada sel tubuh, sehingga dapat mencegah atau mengurangi terjadinya kerusakan sel (Abdul, 2003).

Radikal bebas adalah suatu senyawa atau molekul yang mengandung satu atau lebih electron yang tidak berpasangan pada orbital luarnya. Adanya elektron tidak berpasangan menyebabkan senyawa tersebut sangat reaktif mencari pasangan, dengan cara menyerang dan mengikat elektron yang berada di sekitarnya sehingga dapat memicu timbulnya penyakit (Sunarni, et al., 2007).

Akibat dari radikal bebas adalah sel menjadi rusak, dan menyebabkan berbagai jenis penyakit, seperti kanker, anemia, asma, artritis, inflamasi, degerenasi syaraf, parkinson, dan proses penuaan dini (Polterait, 1997).

Pengujian aktivitas antioksidan dapat dilakukan secara in vitro dengan metode DPPH (1,1-difenil-2-pikrilhidrazil). Metode DPPH memberikan informasi reaktivitas senyawa yang diuji dengan suatu radikal stabil. DPPH memberikan serapan kuat pada panjang gelombang $517 \mathrm{~nm}$ dengan warna violet gelap. Penangkap radikal bebas menyebabkan elektron menjadi berpasangan yang kemudian menyebabkan penghilangan warna yang sebanding dengan jumlah elektron yang diambil (Sunarni, et al., 2007).

Berdasarkan pembentukan dan asalnya, antioksidan dalam tubuh makhluk hidup digolongkan menjadi dua golongan yaitu antioksidan endogen dan antioksidan eksogen. Antioksidan endogen adalah antioksidan secara alami terdapat dalam tumbuhan, hewan, manusia terdapat baik intra maupun ekstraselular. Sedangkan antioksidan eksogen adalah antioksidan yang ditambahkan dari luar, pada produk makanan sering ditambahkan antioksidan untuk menghambat kerusakan oksidatif sedangkan manusia sering mengonsumsi antioksidan untuk menghambat terjadinya stres oksidatif (Scheibmeir HD, et al., 2005).

Tumbuhan di Indonesia yang mempunyai potensi sebagai antioksidan salah satunya adalah tumbuhan mahoni (Swietenia mahagoni Jacq.) Mahoni merupakan salah satu tumbuhan yang banyak dikenal di Indonesia dan banyak dibudidayakan, kulit dan biji mahoni banyak digunakan sebagai obat tradisional, biji mahoni daun kecil berkhasiat sebagai obat tekanan darah tinggi, encok, eksim, masuk angin, malaria, demam, anemia, diare dan disentri (Hariana, 2007).

Mahoni belum banyak diteliti dan belum ada penelitian tentang antioksidan, sehingga pada penelitian ini penulis tertarik melakukan uji aktivitas antioksidan tanaman kulit batang mahoni (Swietenia mahagoni Jacq) dengan menggunakan metode DPPH (1,1-difenil-2-pikrilhidrazil). Dan pelarut yang digunakan adalah etanol dengan konsentrasi 100, 150, 200 dan $250 \mathrm{mg} / \mathrm{L}$.

\section{METODOLOGI PENELITIAN}

\section{Waktu dan Tempat Penelitian}

Pengambilan sampel dilakukan desa Rurukan, di kota Tomohon Sedangkan untuk preparasi sampel, pengamatan dan analisis data penelitian ini dilakukan di Laboratorium Penelitian Farmasi lanjutan (Farmakognosi Fitokimia dan Laboratorium Analisis Farmasi) Program Studi Farmasi, Fakultas Matematika dan Ilmu Pengetahuan Alam, 
Universitas Sam Ratulangi pada bulan Desember 2018 - Januari 2019.

\section{Jenis Penelitian}

Jenis penelitian yaitu eksperimen laboratorium dengan rancangan penelitian dimana sampel kulit batang Switenia mahagoni Jacq. disiapkan dan diekstraksi dengan metode maserasi menggunakan pelarut etanol kemudian dilakukan uji aktivitas antioksidan terhadap DPPH $(1,1-$ difenil-2-picrylhydrazyl).

Alat

Alat-alat yang digunakan pada penelitian ini yaitu gunting pisau, wadah botol, cawan porselin, ziplok, sarung tangan, talenan, gelas ukur, erlenmeyer, kaca arloji, labu ukur $(100 \mathrm{~mL}$ dan $50 \mathrm{~mL})$, tabung reaksi, rak tabung reaksi, baker glass, vortex (Benchmark), corong, pipet tetes, mikro pipet, timbangan digital (AE ADAM), spatula, ayakan mesh 65, oven dan spektrofotometer UV-Vis (UV-1800).

\section{Bahan}

Bahan-bahan yang digunakan pada penelitian ini yaitu kulit batang Switenia mahagoni Jacq., etanol 96\%, kertas saring, tissue, alumunium foil, kertas label, serbuk vitamin c p.a dan serbuk DPPH (1,1-difenil2-picrylhydrazyl).

\section{Prosedur Penelitian}

\section{Pengambilan Sampel}

Sampel kulit batang Switenia mahagoni Jacq. diperoleh dari depan Fakultas Matematika dan Ilmu Pengetahuan Alam, Universitas Sam Ratulangi, Kota
Manado. Sampel diambil dengan menggunakan alat bantu (gunting pisau dan ziplok), kemudian di masukkan dalam ziplok dan diberikan lebel.

\section{Identifikasi Tanaman}

Identifikasi tanaman dilakukan di Laboratorium Taksonomi Tumbuhan, Jurusan Biologi Fakultas Matematika dan ilmu Pengetahuan Alam, Universitas Sam Ratulangi Manado.

\section{Preparasi Sampel}

Di Laboratorium Farmakognosi Fitokimia, sampel yang didapat langsung dibersihkan dari pengotor, dikeringkan di udara terbuka suhu ruangan. Setelah kering, dihaluskan dengan penghalus sampai menjadi serbuk dan diayak kemudian hasil ayakan dimasukkan ke dalam botol.

\section{Ekstraksi}

100 gram dan direndam dengan menggunakan larutan etanol 96\%. Metode ekstraksi dilakukan dengan cara merendam sampel dengan larutan penyaring selama 3 kali 24 jam pada temperatur kamar yang dilindungi dari cahaya dan sesekali dikocok. Hasil ekstraksi kemudian disaring menggunakan kertas saring $16 \times 16 \mathrm{~cm}$, kemudian diambil filtratnya dan residu di buang. Setelah proses ekstraksi menghasilkan 3 filtrat yang kemudian dicampur menjadi satu. Filtrat tersebut dipekatkan dengan menggunakan oven pada suhu $40^{\circ} \mathrm{C}$ sampai etanol menguap. 


\section{Pembuatan Larutan Stok 100 ml}

Sebanyak $100 \mathrm{mg}$ ekstrak etanol Swietenia mahagoni Jacq. Dilarutkan didalam etanol $96 \%$ ad. $100 \mathrm{~mL}$ (konsentrasi 1000 ppm). Dengan masing-masing konsentrasi $250 \mathrm{mg} / \mathrm{L}, 200 \mathrm{mg} / \mathrm{L}, 150 \mathrm{mg} / \mathrm{L}$, dan $100 \mathrm{mg} / \mathrm{L}$ dihitung dengan menggunakan rumus pengenceran, yaitu :

$$
\mathbf{M}_{1} \cdot \mathbf{V}_{1}=\mathbf{M}_{2} \cdot \mathbf{V}_{2}
$$

Pada keempat konsentrasi, masing-masing hasil yang didapatkan dari hasil $\mathrm{V}_{1}$ dipipet dan ditambahkan etanol 96\% hingga mencapai tanda batas $(10 \mathrm{~mL})$, kemudian dipindahkan ke dalam tabung reaksi dan ditutup dengan menggunakan aluminium foil untuk digunakan pada perlakuan selanjutnya.

\section{Pembuatan Larutan DPPH}

Penentuan aktivitas penangkal radikal bebas DPPH menurut Burda dan Olezek (2001). Sebanyak $4 \mathrm{mg}$ serbuk DPPH ditimbang dan dilarutkan dalam etanol 96\% sebanyak $100 \mathrm{~mL}$. Selanjutnya larutan stok DPPH dilakukan pengujian kontrol, di uji pada spektrofotometer UVVis dengan panjang gelombang antara 400$800 \mathrm{~nm}$.

\section{Pengujian Larutan Kontrol DPPH dan Pengujian Sampel}

Setelah pengujian sampel dan pengujian kontrol, dilanjutkan pada pengujian vitamin $\mathrm{C}$ p.a sebagai kontrol pembanding. Kaca arloji ditimbang, vitamin C ditimbang sebanyak $10 \mathrm{mg}$. Kemudian, vitamin C p.a dilarutkan dalam etanol $96 \%$ sebanyak $10 \mathrm{~mL}$, buat larutan stok dengan konsentrasi yang sama sebelumnya yaitu konsentrasi $250 \mathrm{mg} / \mathrm{L}, 200 \mathrm{mg} / \mathrm{L}, 150 \mathrm{mg} / \mathrm{L}$ dan $100 \mathrm{mg} / \mathrm{L}$ dengan ditambahkan masingmasing larutan dengan etanol p.a mencapai tanda batas $(10 \mathrm{~mL})$, dengan pengulangan sebanyak 3 kali pada masing-masing konsentrasi. Pada masing-masing konsentrasi di pipet $2 \mathrm{~mL}$ dan ditambahkan larutan DPPH $2 \mathrm{~mL}$, di vorteks selama 2 menit dan diinkubasi selama 30 menit pada suhu $37^{\circ}$ C. Sampel vitamin C p.a diuji pada spektrofotometer UV-Vis dengan panjang gelombang $517 \mathrm{~nm}$.

\section{Pengujian Aktivitas Antioksidan Dengan Metode DPPH}

Penentuan aktivitas penangkal radikal bebas DPPH menurut Burda dan Olezek (2001). Diambil sebanyak $2 \mathrm{~mL}$ ekstrak etanol kulit batang Swietenia mahagoni Jacq. dengan konsentrasi 250 $\mathrm{mg} / \mathrm{L}, 200 \mathrm{mg} / \mathrm{L}, 150 \mathrm{mg} / \mathrm{L}$ dan $100 \mathrm{mg} / \mathrm{L}$ ditambahkan masing-masing $2 \mathrm{~mL}$ larutan DPPH dalam etanol dan divorteks selama 2 menit. Berubahnya warna ungu menjadi warna kuning menunjukkan efisiensi penangkal radikal bebas.Diukur absorbansi pada spektrofotometer UV-Vis dengan panjang gelombang $517 \mathrm{~nm}$ setelah diinkubasi selama 30 menit. Kemudian diamati perbandingannya dengan vitamin $\mathrm{C}$ sebagai standar. Setelah absorbansi didapat, Aktivitas penangkapan radikal bebas (persen inhibisi) dihitung sebagai persentase berkurangnya warna DPPH dengan menggunakan rumus berikut:

$\%$ inhibisi $=1-\frac{\text { absorbansi sampel }}{\text { absorbansi kontrol }} \times 100 \%$ 


\section{HASIL DAN PEMBAHASAN}

Dari hasil pengukuran pada penelitian ini diperoleh absorbansi yang kemudian digunakan untuk perhitungan nilai persen inhibisi atau persen perendaman senyawa antioksidan terhadap DPPH. Data persen inhibisi ekstrak etanol Swietenia mahagoni Jacq. dan Vitamin C p.a sebagai pembanding disajikan pada Tabel 1 berikut ini :

Tabel 1. Hasil pengujian perbandingan antara Ekstrak Etanol Swietenia mahagoni Jacq. dan Vitamin $\mathbf{C}$ p.a

\begin{tabular}{|c|c|c|c|c|c|}
\hline \multirow{2}{*}{\multicolumn{2}{|c|}{ Pengulangan }} & \multicolumn{4}{|c|}{ Konsentrasi } \\
\hline & & I & II & III & Rata-Rata \\
\hline \multirow{2}{*}{$\begin{array}{c}100 \\
\mathrm{mg} / \mathrm{L}\end{array}$} & Ekstrak & $7,50 \%$ & $13,10 \%$ & $10,50 \%$ & $10,36 \%$ \\
\hline & Vit.C & $84,50 \%$ & $86,80 \%$ & $86,10 \%$ & $85,80 \%$ \\
\hline \multirow{2}{*}{$\begin{array}{r}150 \\
\mathrm{mg} / \mathrm{L}\end{array}$} & Ekstrak & $10,10 \%$ & $15,20 \%$ & $17,00 \%$ & $14,10 \%$ \\
\hline & Vit. C & $86,10 \%$ & $87,20 \%$ & $87,70 \%$ & $87,00 \%$ \\
\hline \multirow{2}{*}{$\begin{array}{c}200 \\
\mathrm{mg} / \mathrm{L}\end{array}$} & Ekstrak & $13,90 \%$ & $17,30 \%$ & $11,60 \%$ & $14,26 \%$ \\
\hline & Vit. C & $87,60 \%$ & $88,00 \%$ & $86,60 \%$ & $87,40 \%$ \\
\hline \multirow{2}{*}{$\begin{array}{c}250 \\
\mathrm{mg} / \mathrm{L}\end{array}$} & Ekstrak & $17,40 \%$ & $24,70 \%$ & $22,40 \%$ & $21,50 \%$ \\
\hline & Vit. C & $87,60 \%$ & $87,50 \%$ & $87,90 \%$ & $87,66 \%$ \\
\hline
\end{tabular}

Uji aktivitas antioksidan suatu tanaman sangat penting dilakukan untuk mengetahui apakah dari tanaman tersebut terbukti memiliki aktivitas pengikatan terhadap radikal bebas. Pada penelitian ini, tanaman yang digunakan yaitu kulit batang Swietenia mahagoni Jacq.

Benih mahoni telah dibuktikan memiliki aktivitas sebagai antitumor antiinflamasi, dan antimutagenisitas (Guevera, et al., 1996.) Biji mahoni juga memiliki aktivitas antibakteri dan antifungi (Murningsih, et al., 2005). Sehingga tidak menutup kemungkinan untuk kulit batang Swietenia mahagoni Jacq. juga dapat mengandung senyawa metabolit sekunder sebagai aktivitas antioksidan yang diproduksi ketika mempertahankan diri dari lingkungan maupun dari serangan organisme lain.

Sebagai parameter pengujian antioksidan dilakukan dengan menggunakan metode DPPH (1,1-difenil-2-pikrilhidrazil). Pemilihan metode ini karena merupakan metode yang sederhana, mudah, cepat dan peka serta hanya memerlukan sedikit sampel untuk evaluasi aktivitas antioksidan. DPPH (1,1-difenil-2-pikrilhidrazil) merupakan radikal bebas sintetik berwarna ungu yang 
banyak digunakan dalam uji aktivitas antioksidan. Larutan radikal bebas DPPH memiliki atom nitrogen yang tidak berpasangan. Reaksi DPPH dengan atom hidrogen yang terdapat dalam antioksidan dapat membuat larutan DPPH menjadi berkurang reaktivitasnya, yang ditunjukkan dengan memudarnya warna ungu menjadi kuning. Perubahan warna ini mengakibatkan perubahan absorbansi pada panjang gelombang maksimum DPPH menggunakan spektrofotometri UV-Vis yang menjadi patokan (Molyneux, 2004). Penetuan panjang gelombang serapan maksimum $(\lambda$ maks) larutan DPPH dilakukan dengan mengukur absorbansi larutan pada panjang gelombang antara 400-800 nm. Hasil yang didapatkan pada penelitian ini adalah 517 nm dan memiliki absorbansi kontrol 0,715 (Lampiran 5).

dalam penelitian ini menggunakan perbandingan $1: 1$ yang artinya $2 \mathrm{~mL}$ larutan DPPH dicampurkan dengan $2 \mathrm{~mL}$ larutan sampel (ekstrak etanol kulit batang Swietenia mahagoni Jacq. atau vitamin C) pada tiap konsentrasi yang berbeda-beda. Sempurnya campuran DPPH dan ekstrak dibantu dengan perlakuan di vortex selama 2 menit. Berkurangnya intensitas warna larutan DPPH tersebut dapat menunjukkan bahwa terjadi reaksi antara atom hidrogen yang dilepas oleh bahan uji dengan molekul radikal DPPH sehingga terbentuk senyawa 1,1-difenil-2-pikrilhidrazil yang berwarna kuning (Rumagit, 2015).

Konsentrasi ekstrak etanol kulit batang Swietenia mahagoni Jacq. yang digunakan adalah $250 \mathrm{mg} / \mathrm{L}, 200 \mathrm{mg} / \mathrm{L}, 150$ $\mathrm{mg} / \mathrm{L}$, dan $100 \mathrm{mg} / \mathrm{L}$. Masing-masing konsentrasi dicampurkan dengan larutan DPPH dengan perbandingan yang ada. Campuran dihomogenkan dan diinkubasi selama 30 menit pada tempat gelap dengan suhu $37^{\circ} \mathrm{C}$. Hal ini dilakukan untuk menghindari kontaminasi dan mengoptimalkan aktivitas DPPH agar terjadi reaksi antara DPPH dengan sampel yang diuji (Hatano, et al., 1998). Setelah diinkubasi, kemudian masing-masing ekstrak dilakukan pengukuran absorbansi dengan menggunakan spektrofotometer pada panjang gelombang serapan maksimum $(\lambda$ maks) DPPH $517 \mathrm{~nm}$. Pada tiap konsentrasi dilakukan sebanyak 3 kali pengulangan.

Pembanding yang digunakan sebagai kontrol positif adalah Vitamin C p.a dimana sebagai pembanding karena berfungsi sebagai antioksidan sekunder yaitu menangkap radikal bebas, mencegah terjadinya reaksi berantai, aktivitas antioksidannya sangat tinggi, mudah diperoleh dan vitamin $\mathrm{C}$ lebih polar dari vitamin yang lain. Vitamin $\mathrm{C}$ mempunyai gugus hidroksi bebas yang bertindak sebagai penangkap radikal bebas (Isnindar, et al., 2011).

Berdasarkan hasil yang diperoleh pada Tabel 1 menunjukkan bahwa pengukuran persen inhibisi pada ekstrak etanol kulit batang Swietenia mahagoni Jacq. memiliki aktivitas antioksidan dan mengalami peningkatan dari konsentrasi 100 $\mathrm{mg} / \mathrm{L}$ sampai dengan $250 \mathrm{mg} / \mathrm{L}$. Pada ekstrak etanol kulit batang Swietenia mahagoni Jacq. dengan konsentrasi $250 \mathrm{mg} / \mathrm{L}$ memiliki persen inhibisi rata-rata paling tinggi yaitu sebesar 21,5\%. Penigkatan persen inhibisi pada ekstrak etanol kulit batang Swietenia mahagoni Jacq.. menandakan bahwa 
konsentrasi ekstrak yang ditambahkan mempengaruhi kemampuan ekstrak dalam merendam radikal bebas. Hal ini didukung oleh penelitian yang dilakukan oleh Hanani, et al., (2005) yang menyatakan bahwa presentasi penghambat atau persen inhibisi terhadap aktivitas radikal bebas akan ikut meningkat seiring dengan meningkatnya konsentrasi. Hasil pengujian perbandingan aktivitas antioksidan ekstrak kulit batang Swietenia mahagoni Jacq. dan Vitamin C (Tabel 1) juga menukjukkan bahwa aktivitas antioksidan ekstrak etanol kulit batang Swietenia mahagoni Jacq. lebih rendah dibandingkan dengan Vitamin C. Rendahnya aktivitas antioksidan ini kemungkinan disebabkan oleh berbagai faktor, diantaranya karena metode ekstraksi yang digunakan kemungkinan tidak cukup menarik komponen kimia yang bersifat antioksidan dalam kulit batang Swietenia mahagoni Jacq. Selain itu karena vitamin C merupakan senyawa murni sedangkan ekstrak etanol kulit batang Swietenia mahagoni Jacq. masih merupakan senyawa campuran dan belum diketahui kandungan senyawanya yang bersifat antioksidan, dimana adanya senyawa yang tidak bersifat antioksidan kemungkinan bisa mempengaruhi aktivitas antioksidan ekstrak etanol kulit batang Swietenia mahagoni Jacq. itu sendiri.

\section{KESIMPULAN}

Berdasarkan dari hasil penelitian yang telah dilakukan maka, dapat disimpulkan bahwa ekstrak etanol kulit batang Swietenia mahagoni Jacq. memiliki aktivitas antioksidan disetiap konsentrasi. Aktivitas antioksidan tertinggi terlihat pada konsentrasi tertinggi.

\section{SARAN}

Perlu dilakukan penelitian kuantitatif lebih lanjut untuk mengetahui senyawa aktif yang terkandung dalam ekstrak etanol kulit batang Swietenia mahagoni Jacq. dan pengujian aktivitas antioksidan dengan metode lain dan sebaiknya membandingkan hasilnya dengan penelitian ini.

\section{DAFTAR PUSTAKA}

Abdul. M. 2003. Peranan radikal bebas dan antioksidan dalam kesehatan dan penyakit.

http://www.intisari.com/radikal.html.

Burda, S., Oleszek, W., (2001) Antioxidant and Antiradical Activities of Flavonoids. J. Agric. Food Chem. 49: 2774-2779.

Guevera AP, Apilado A, Sakarai H, Kozuka M, dan Tokunda. 1996. H. Antiinflammatory, antimutagenecity and antitumor activity of mahagony seeds Swietenia macrophylla (Meliaceae). Phill J of Sci 125: 271278.

Isnindar, Wahyuono, S., Setyowati, E. P. (2011). Isolasi dan Identifikasi Senyawa Antioksidan Daun Kesemek (Diopyroskaki Thunb) dengan Metode DPPH. Majalah Obat Tradisional. 16 (3) : 157-164.

Hariana, A. (2007). Tumbuhan Obat dan khasiat, Jakarta: Penebar Swadaya. Halaman 111.

Hatano, T., H. Kagawa, T.T. Yasuhara, I. Okuda. 1998. Two New Flavonoids and $\mathrm{O}$ ther Consituents in 
Licorice Roots : Their

Relative Astringency and Radical

Scavenging Effect. Chem. Pharm.

Bull.

Molyneux, P. 2004. The Use of The Stable

Free Radical Diphenylpicrylhydrazyl

(DPPH) For Estimating

Antioxidant Activity. J.Sci. Technol. 26(2) : 211-219.

Murningsih, Subekti T, Matsuura H, Takahashi K, Yamasaki M. 2005. Evaluation of the inhibitory activities of extract of Indonesian traditional medicinal plant against Plasmodium falsiparum and Babesia gibsoni. J. Vet. Med. Sci. 67 : 829831.

Scheibmeir HD, Christensen K, Whitaker $\mathrm{SH}$, Jegaethesan J, Clancy R, Pierce JD. A review of free radicals and antioxidants for critical care nurses. Intensive and Critical Care Nurs 2005; 21:24-8.1856. Jakarta : Progam Studi Strata Satu Universitas Indonesia, 2012).

Sunarni, T., Pramono, S., Asmah, R. 2007, Flavonoid antioksidan penangkap radikal dari daun kepel (Stelechocarpus burahol (B1.) Hook f. \& Th.), M.F.I., 18 (3) : 111-116. 